\title{
Evaluasi Kinerja Campuran Beraspal Lapis Aus (AC-WC) dengan Bahan Tambah Limbah Plastik Kresek
}

\section{Iwan Susanto $^{1^{*}}$, Nyoman Suaryana ${ }^{1}$}

Balai Litbang Perkerasan Jalan, Pusat Litbang Jalan \& Jembatan, Kementerian Pekerjaan Umum dan Perumahan Rakyat ${ }^{1}$ Koresponden*, Email: iwan.susanto@pusjatan.pu.go.id

\begin{tabular}{lcl}
\hline & Info Artikel & Abstract \\
\hline Diajukan & 10 Maret 2019 & Plastic waste is an environment problem that must be resolve. In other side, pavement sector \\
Diperbaiki & 8 Juli 2019 & has problem of road destruction. Polymer contained of plastic has potential to be use pavement \\
Disetujui & 22 Juli 2019 & material. This research aims to find out the performance of asphalt mixtures AC-WC with \\
& plastic waste. The experimental methods by testing laboratory and applied was selected method. \\
& The result of characteristic test, showed that stability of asphalt mixtures with plastic waste \\
& increased from 1100kg to 1400kg-1500kg. Result of durability for asphalt mixtures with plastic \\
& waste increased for residual stability value, from 90,54\% become 94,70\%. The result of \\
& deformation resistance test showed that asphalt mixtures with plastic waste was increased of \\
& dynamic stability value. The modulus resilient value was decreased at the time of temperature \\
& increased and increased after added plastic waste is the characteristic of asphalt mixtures with \\
& plastic waste. The effective of plastic waste percentage is $6 \%$ from asphalt gravity. Extraction \\
& testing showed that mixture of plan and at field is no significant difference. Result of IRI value \\
& for pavement condition is obtained $<4$ and 4-8.
\end{tabular}

Abstrak

Limbah plastik merupakan permasalahan lingkungan yang harus diatasi. Disisi lain, bidang perkerasan jalan mengalami permasalahan kerusakan jalan. Limbah plastik kresek yang mengandung polimer berpotensi sebagai bahan perkerasan jalan. Penelitian ini bertujuan untuk mengetahui kinerja campuran beraspal panas AC-WC dengan limbah plastik. Metode eksperimen terpilih, dilakukan dengan pengujian laboratorium serta diaplikasikan di lapangan. Hasil uji karakteristik, menunjukan nilai stabilitas campuran dengan limbah plastik mengalami peningkatan dari $1100 \mathrm{~kg}$ menjadi $1400 \mathrm{~kg}-1500 \mathrm{~kg}$. Hasil uji durabilitas, campuran dengan limbah plastik mengalami peningkatan nilai stabilitas sisa, dari $90,54 \%$ menjadi $94,70 \%$. Hasil uji ketahanan deformasi menunjukan campuran beraspal dengan limbah plastik mengalami peningkatan nilai stabilitas dinamis. Nilai modulus resilien turun saat peningkatan temperatur dan meningkat setelah ditambah limbah plastik, merupakan perilaku campuran dengan limbah plastik. Kadar plastik paling efektif adalah $6 \%$ dari berat aspal. Hasil uji ektraksi menunjukan antara campuran

Kata kunci: deformasi, durabilitas, IRI, rencana dan lapangan tidak terdapat perbedaan yang signifikan. Nilai IRI kondisi limbah plastik, modulus resilien, stabilitas perkerasan diperoleh nilai $<4$ dan $4-8$.

\section{Pendahuluan}

Kebutuhan bahan jalan untuk campuran beraspal dan lapis fondasi di seluruh wilayah terus meningkat[1]. Spesifikasi umum Bina Marga Tahun 2018 telah mensyaratkan tentang kualitas bahan campuran beraspal, dimana kualitas bahan akan berpengaruh terhadap mutu campuran beraspal[2]. Rendahnya mutu bahan merupakan salah satu penyebab kerusakan jalan. Hal tersebut ditambah dengan meningkatnya volume lalu lintas, baik dalam hal jumlah, beban, maupun kecepatannya serta kondisi iklim tropis menjadi alasan lain banyak ditemukannya kerusakan jalan. Berdasarkan beberapa penelitian menunjukkan bahwa penggunaan aspal yang tidak sesuai sering menjadi penyebab terjadinya kerusakan dini berupa alur, gelombang dan naiknya aspal ke permukaan. Berbagai macam modifikasi untuk meningkatkan mutu aspal telah dilakukan untuk mengatasi permasalahan tersebut[3]

Di sisi lain terdapat permasalahan di sektor lingkungan, yaitu pencemaran baik tanah maupun perairan oleh plastik kresek. Tidak dipungkiri bahwa kantong plastik jenis kresek telah menjadi bagian hidup manusia dan sulit untuk dipisahkan. Plastik kresek merupakan bahan anorganik buatan yang tersusun dari bahan-bahan kimia yang cukup berbahaya bagi lingkungan. Sampah plastik sangatlah sulit untuk diuraikan secara alami, untuk menguraikan sampah plastik membutuhkan kurang lebih 80 tahun agar dapat terdegradasi secara sempurna. Oleh karena itu penggunaan 
bahan plastik dapat dikatakan tidak bersahabat bagi lingkungan apabila digunakan tanpa menggunakan batasan tertentu[4]. Indonesia merupakan negara penghasil limbah plastik terbesar nomor dua di dunia sehingga pemanfaatan limbah plastik merupakan isu penting guna penyelamatan lingkungan[5].

Untuk mengatasi permasalahan kebutuhan bahan jalan yang terus meningkat, kerusakan jalan yang sering terjadi, serta masalah lingkungan oleh limbah plastik kresek, salah satunya adalah dengan cara pemanfaatan limbah plastik pada bidang perkerasan jalan sebagai bahan tambah campuran beraspal panas. Plastik yang sering kita gunakan sehari-hari mengandung polimer[6] dan kandungan polimer tersebut berpotensi untuk digunakan sebagai bahan tambah perkerasan jalan.

\section{Polimer}

Polimer sering digunakan dalam pembuatan perkerasan jalan sebagai modifier aspal. Penambahan bahan aditif jenis polimer dalam jumlah kecil ke dalam aspal terbukti dapat meningkatkan kinerja aspal dan memperpanjang umur kekuatan atau masa layan perkerasan tersebut[7]. Polimer juga dapat meningkatkan daya tahan perkerasan terhadap berbagai kerusakan, seperti deformasi permanen, retak akibat perubahan suhu, fatigue damage, serta pelepasan material[8].

Aspal modifikasi polimer telah diyakini memberikan kinerja yang lebih baik, jika pemilihan jenis aspal modifikasi yang sesuai dengan kondisi lokasi, beban lalulintas dan lingkungan yang sesuai.

Polimer secara umum dapat diklasifikasikan menjadi

a) thermoplastic crystalline polymer (plastomer),

b) thermoplastic rubber (elastomer) dan

c) thermosetting polymer.

Plastomer secara umum disebut sebagai bahan polimer plastik, antara lain polyethylene ( $\mathrm{PE})$, polypropylene $(\mathrm{PP})$, polyvinyl chloride (PVC), polystyrene (PS), ethylene vinyl acetate (EVA), dan ethyl methyl acrylate (EMA). Sementara elastomer yang banyak digunakan sebagai modifier antara lain natural rubber, Styrene-butadine-styrene block copolymer (SBS), Styrene-butadiene rubber (SBR), Styrene-isoprene-styrene block copolymer (SIS), Polybutadiene (PBD), dan Polyisoprene.

Spesifikasi di India membagi limbah plastik yang sering digunakan untuk campuran beraspal ke dalam 5 tipe, yaitu Low Density Polyethylene (LDPE), High Density Polyethylene (HDPE), Polyethylene Teryphtalate (PET), Polypropylene (PP), Polystyrene (PS)[9].
Penggunaan polimer sebagai modifikasi campuran beraspal telah banyak dilakukan oleh para peneliti, dan telah terbukti efektif meningkatkan mutu campuran serta secara luas telah banyak diterapkan [10]. Plastik kresek merupakan salah satu polimer dan merupakan jenis polimer plastomer, tipe LPDE, dan bukan merupakan bahan beracun. Titik leleh limbah plastik kresek ini hanya sampai $150^{\circ} \mathrm{C}$ di AMP. Sementara temperatur plastik kresek terdekomposisi adalah $\pm 300^{\circ} \mathrm{C}$

Terdapat dua jenis proses dalam pemanfaatan limbah plastik dalam campuran beraspal yaitu wet process dan dry process. Wet process merupakan jenis proses yang mencampurkan limbah plastik dengan aspal untuk melakukan modifikasi terhadap aspal. Sementara dry process merupakan proses yang mencampurkan limbah plastik dengan agregat panas kemudian dicampur dengan aspal untuk memodifikasi agregat [9].

\section{Penelitian Terdahulu}

Pemanfaatan limbah plastik sebagai bahan perkerasan jalan sebenarnya bukanlah hal yang baru. Seorang peneliti di India telah memanfaatkan plastik sebagai bahan jalan dan telah diterapkan pada $>20.000$ mil jalan di India. Metoda yang digunakan di India ini, limbah plastik digunakan untuk memodifikasi agregat yang artinya limbah plastik digunakan untuk meningkatkan mutu agregat[11].

Pada tahun 2017 Pusat Penelitian dan Pengembangan Jalan dan Jembatan (Pusjatan), telah melakukan kajian terhadap pemanfaatan limbah plastik sebagai bahan campuran beraspal panas di laboratorium serta menyusun pedoman perancangan dan pelaksanaan penggunaan limbah plastik sebagai campuran beraspal. Salah satu penelitian skala laboratorium Pusjatan yaitu Plastic Bag Waste on Hotmixture Asphalt as Modifier telah membuktikan kinerja campuran beraspal dengan bahan tambah limbah plastik yang efektif meningkatkan mutu campuran. Untuk mengetahui kinerja campuran beraspal dalam skala lapangan, maka dilakukan uji coba penerapan skala terbatas campuran beraspal menggunakan limbah plastik jenis LDPE di jalan lingkungan Kampus Pusjatan di Bandung dengan panjang jalan 300m dan lebar 4,65m. Jenis campuran beraspal yang digunakan adalah tipe AC-WC menggunakan aspal minyak penetrasi 60 (Pen. 60).

Tujuan dari penelitian ini adalah untuk mengetahui dan mengevaluasi kinerja campuran beraspal AC-WC yang menggunakan aspal Pen. 60 dengan bahan tambah limbah plastik kresek jenis LPDE. 


\section{Metode}

Penelitian terhadap kinerja campuran beraspal dengan bahan tambah limbah plastik ini menggunakan metode eksperimen di laboratorium dan diterapkan dalam skala lapangan. Analisa dilakukan dengan melakukan pengujian laboratorium maupun pengujian lapangan.

Tahapan penelitian meliputi kajian literatur, pengujian mutu bahan, perencanaan kadar efektif limbah plastik LPDE dalam campuran, perencanaan campuran dengan uji Marshall, pengujian kepadatan, pengujian ketidakrataan, dan pengujian ekstraksi.

Pada penelitian ini khusus menggunakan limbah plastik kresek jenis LDPE yang telah dicacah dengan range ukuran $0,60 \mathrm{~mm}-9,5 \mathrm{~mm}$. Metode pencampuran yang digunakan adalah metode kering atau dry process. Limbah plastik kresek dimasukan melalui pugmill di AMP dan dicampur dengan agregat panas agar menyeliputi agregat sebelum disemprotkan aspal.

\section{Pengujian Mutu Bahan dan Campuran Beraspal}

Pengujian mutu bahan dilakukan sampai diperoleh mutu yang sesuai disyaratkan. Acuan untuk pengujian mutu bahan adalah Spesifikasi Umum Bina Marga Tahun 2010 Revisi 3.

Pengujian mutu juga dilakukan terhadap mutu plastik kresek. Bentuk plastik yang digunakan adalah plastik yang telah dicacah dengan alat mencacah yang diameter ukuran maksimal adalah $9 \mathrm{~mm}$.

Perencanaan campuran beraspal adalah kegiatan yang dilakukan untuk memperoleh komposisi agregat dan aspal dalam campuran. Untuk campuran beraspal plastik acuan yang digunakan adalah Spesifikasi Khusus Interm Seksi SKh-1.6.10. Spesifikasi untuk perencanaan campuran beraspal dengan metode Marshall didasarkan pada SNI 2489:2014.

\section{Pengujian Kadar Efektif Plastik dalam Campuran}

Kadar efektif plastik cacah dalam campuran ditentukan melalui pengujian. Pengujian kadar efektif limbah plastik dilakukan untuk mengetahui berapa persentase limbah plastik yang paling efektif dalam meningkatkan mutu campuran beraspal. Presentase yang digunakan adalah $0 \%, 5 \%, 6 \%, 8 \%$, dan $10 \%$ dari berat aspal.

\section{Pengujian Stabilitas Campuran Beraspal}

Nilai stabilitas campuran beraspal merupakan kemampuan lapisan perkerasan menerima beban lalu lintas tanpa terjadi perubahan bentuk tetap seperti gelombang, alur ataupun bleeding. Kemampuan tersebut terjadi sebagai hasil geseran antar butir, penguncian antar partikel dan daya ikat yang baik dari aspal. Semakin tinggi nilai stabilitas menunjukan semakin kuat campuran dalam menahan beban [12]. Namun, stabilitas yang terlalu tinggi menyebabkan lapisan menjadi kaku dan cepat retak disamping itu karena volume antar agregat kurang, mengakibatkan kebutuhan aspal mudah lepas sehingga durabilitas menjadi rendah.

Pada penelitian ini nilai stabilitas akan dibandingkan antara nilai stabilitas campuran beraspal tanpa plastik dengan nilai stabilitas campuran beraspal yang telah ditambahkan dengan plastik.

\section{Pengujian Modulus Resilien}

Kondisi mayoritas campuran beraspal jalan tidak bersifat elastis karena mengalami deformasi permanen pada tiap pengulangan pembebanan. Namun demikian jika beban tersebut relatif kecil dibandingkan dengan kekuatan material dan mengalami pengulangan pembebanan yang tinggi, sehingga deformasi yang terjadi pada setiap pengulangan pembebanan adalah hampir dapat kembali sempurna (nearly complete recoverable) dan proporsional terhadap pembebanan, maka material tersebut dianggap material yang elastis [13]. Pengujian modulus resilien dapat dilakukan dengan uji tarik langsung (indirect tensile test). Faktor utama yang perlu diperhatikan pada pengujian modulus resilien campuran beraspal adalah temperatur dan frekwensi pembebanan. Dua faktor ini memberikan pengaruh yang besar pada nilai modulus resilien[14].

\section{Pengujian Ketahanan Deformasi}

Menurut NCHRP deformasi permanen atau rutting adalah penurunan permukaan pada jejak roda yang disebabkan oleh deformasi plastis pada setiap atau seluruh lapisan perkerasan dan subgrade[15]. Deformasi plastis umumnya disebabkan oleh idensifikasi atau kompresi satu dimensi atau konsolidasi, dan pergerakan arah lateral atau plastic flow dari lapis perkerasan (campuran beraspal, agregat base/sub base dan tanah dasar). Pengujian terhadap ketahanan deformasi alur dilakukan dengan alat WTM (Wheel Tracking Machine). Semakin tinggi nilai kedalaman alur, deformasi awal, dan kecepatan deformasi menunjukan ketahanan campuran yang rendah. Untuk nilai stabilitas dinamis, menyatakan bahwa semakin tinggi nilai tersebut maka ketahanan terhadap deformasi adalah lebih baik[14].

\section{Pengujian Kepadatan Lapangan}

Kepadatan merupakan salah satu faktor penting untuk menghasilkan kinerja perkerasan lentur jalan yang baik. Pekerjaan pemadatan di lapangan yang dilakukan menyebabkan pengurangan kadar rongga material, mengoptimalkan 
rangka butiran dan meningkatkan kerapatan material[16]. Kepadatan merupakan tingkat kerapatan (density) campuran setelah dipadatkan. Nilai kepadatan dipengaruhi oleh beberapa faktor seperti gradasi campuran, jenis dan kualitas bahan penyusun, faktor pemadatan termasuk jumlah pemadatan dan temperatur pemadatan, kandungan aspal dan penggunaan bahan tambah (additive) dalam campuran. Kepadatan yang tinggi akan meningkatkan kestabilan dan kekuatan campuran serta mengurangi tendensi terjadinya alur-alur bekas roda akibat lalu lintas[17]

Job Standard Density (JSD) merupakan perhitungan dari perbandingan antara kepadatan laboratorium dengan kepadatan di lapangan pada saat penerapan. Perhitungan JSD adalah sesuai dengan Persamaan 1.

$\mathrm{JSD}=\frac{\text { Kepadatan Laboratorium }}{\text { Kepadatan Lapangan }} \times 100 \%$

\section{Pengujian Ekstraksi}

Ekstraksi adalah pemisahan campuran dua atau lebih bahan dengan cara menambahkan pelarut yang dapat melarutkan salah satu yang ada dalam campuran tersebut. Pelarut yang bisa digunakan dalam proses ekstraksi antara lain spiritus, pertamax, bensin, minyak tanah. Tujuan dilakukan proses ekstraksi yaitu untuk mengetahui kadar aspal dan gradasi agregat yang terdapat dalam campuran aspal yang dibuat (mix design). Nilai kadar aspal dan gradasi digunakan untuk perbandingan antara perencanaan dan pelaksanaan. Salah satu metode yang dikembangkan untuk menguji kandungan kadar aspal dalam campuran (mix design) adalah dengan menggunakan metode ekstrasi menurut prosedur pemeriksaan AASHTO (T-164-80) [18].

\section{Pengujian Ketidakrataan Permukaan Jalan}

Kinerja perkerasan (pavement performance) harus dapat memberikan pelayanan yang aman dan nyaman selama umur rencana. Kenyamanan mengemudi dipengaruhi oleh tingkat ketidakrataan permukaan jalan, sehingga perlu dilakukan pemeriksaan kondisi jalan secara berkala. Pemeriksaan tersebut dimaksudkan untuk mengukur ketidakrataan permukaan jalan yang dapat digunakan dalam program perencanaan pemeliharaan atau peningkatan jalan [19]. Data ketidakrataan dapat diperoleh dengan uji ketidakrataan dan bisa memberikan nilai International Roughness Index (IRI). Nilai IRI merupakan parameter untuk melakukan penilaian kondisi perkerasan secara fungsional [20] Berdasarkan Pedoman Bina Marga kriteria nilai kondisi perkerasan IRI dibagi menjadi 4 kriteria sesuai dengan Tabel 1.
Tabel 1. Kriteria Kondisi Jalan Berdasarkan IRI

\begin{tabular}{cc}
\hline Nilai IRI & Kondisi \\
\hline$<4$ & Baik \\
$4-8$ & Sedang \\
$8-12$ & Rusak Ringan \\
$>12$ & Rusak Berat \\
\hline
\end{tabular}

Sumber: Direktorat Bina Program [21]

\section{Pengujian dan Diskusi}

Seluruh hasil pengujian baik lapangan maupun laboratorium didiskusikan dengan mengundang para pakar bidang perkerasan jalan. Diskusi dan pengujian dari penelitian ini dilakukan di Balai Litbang Perkerasan Jalan, Pusat Litbang Jalan dan Jembatan, Kementerian Pekerjaan Umum dan Perumahan Rakyat. Hasil evaluasi kinerja campuran beraspal AC-WC dengan bahan limbah plastik kresek dianalisa dengan cara membandingkan karakteristik campuran dengan tambahan plastik terhadap campuran beraspal konvensional tanpa limbah plastik

\section{Hasil dan Pembahasan \\ Pengujian Agregat}

Pengujian mutu agregat dilakukan terhadap tiga macam agregat yang digunakan yaitu agregat kasar, agregat sedang, dan agregat halus dimana sumber agregat yang memenuhi spesifikasi adalah dari quari Bantarwaru. Hasil pengujian sifat teknis agregat disajikan pada Tabel 2.

Berdasarkan hasil uji mutu agregat untuk campuran beraspal, parameter setara pasir (sand equivalent $=\mathrm{SE}$ ) tidak masuk spesifikasi yaitu minimum $60 \%$. Nilai setara pasir merupakan identifikasi perbandingan antara bahan agregat halus terhadap bahan-bahan yang dapat merugikan mutu campuran seperti bahan yang lunak, seperti kayu, tanah, atau lempung. Semakin tinggi nilai SE maka kandungan bahan yang merugikan semakin rendah dan sebaliknya.

Agregat halus dengan nilai SE lebih dari $60 \%$ sesuai Spesifikasi Umum Bina Marga Revisi 3 Tahun 2010 pada saat pelaksanaan sulit diperoleh. Pada pertengahan tahun 2018 bersamaan pelaksanaan penelitian ini peraturan tentang SE telah direvisi di Spesifikasi Umum Bina Marga Tahun 2018 yang mensyaratkan nilai SE harus lebih besar dari 50\%. Hal tersebut menyebabkan nilai SE material yang dipilih masuk ke dalam spesifikasi yang ditentukan.

Acuan terhadap nilai spesifikasi agregat yang digunakan sesuai Tabel 2 akhirnya mengacu ke peraturan baru yaitu Spesifikasi Umum Bina Marga Tahun 2018. Karakteristik agregat selain SE mempunyai batasan nilai spesifikasi yang sama atau tidak berubah antara Spesifikasi Umum Bina 
Marga Revisi 3 Tahun 2010 dengan Spesifikasi Umum Bina Marga Tahun 2018.

\section{Pengujian Aspal Penetrasi 60/70}

Penelitian terhadap penerapan dengan limbah plastik ini menggunakan aspal keras 60/70. Hasil pemeriksaan yang dilakukan di laboratorium seperti pada Tabel 3.

\section{Pengujian Plastik Cacah}

Jenis limbah plastik yang digunakan adalah jenis low density polyethylene. Limbah plastik yang digunakan harus dipilah, dicacah, dan dicuci. Cacahan limbah plastik harus kering, bersih, dan terbebas dari bahan organik. Pengujian mutu untuk plastik cacah meliputi uji kadar air dan ketebalan sesuai Tabel 4.

Tabel 2. Karakteristik Agregat

\begin{tabular}{|c|c|c|c|c|}
\hline \multirow{2}{*}{ Jenis Uji } & \multicolumn{3}{|c|}{ Hasil Uji } & \multirow{2}{*}{ Speksifikasi } \\
\hline & Kasar & Sedang & Halus & \\
\hline $\begin{array}{l}\text { Abrasi } 500 \\
\text { putaran, }(\%)\end{array}$ & 27,04 & - & - & Maks. 30 \\
\hline $\begin{array}{l}\text { Abrasi } 100 \\
\text { putaran, }(\%)\end{array}$ & 7,26 & - & - & Maks. 8 \\
\hline $\begin{array}{l}\text { Setara pasir, } \\
(\%)\end{array}$ & - & - & 51 & Min. 60 \\
\hline \multicolumn{5}{|l|}{ Berat jenis } \\
\hline Bulk & 2,56 & 2,57 & 2,57 & \\
\hline$S S D$ & 2,63 & 2,63 & 2,62 & \\
\hline Apparent & 2,75 & 2,73 & 2,72 & \\
\hline $\begin{array}{l}\text { Penyerapan, } \\
(\%)\end{array}$ & 2,77 & 2,20 & 2,17 & Maks. 3,0 \\
\hline $\begin{array}{l}\text { Angularitas, } \\
(\%)\end{array}$ & $\begin{array}{c}100 / 10 \\
0\end{array}$ & $100 / 100$ & - & $95 / 90$ \\
\hline $\begin{array}{l}\text { Kelekatan, } \\
(\%)\end{array}$ & $95+$ & - & - & Min. 95 \\
\hline $\begin{array}{l}\text { Pipih } \\
\text { lonjong, }(\%)\end{array}$ & 1,5 & 1 & - & Maks. 10 \\
\hline $\begin{array}{l}\text { Lolos \#200 } \\
\text { Ag. Kasar, } \\
(\%)\end{array}$ & 0,82 & 0,46 & - & Maks. 2 \\
\hline $\begin{array}{l}\text { Lolos \#200 } \\
\text { Ag. Halus, } \\
(\%)\end{array}$ & - & - & 6,6 & Maks. 10 \\
\hline
\end{tabular}

\section{Pengujian Kadar Efektif Plastik}

Metode terpilih yaitu dry process yang merupakan modifikasi terhadap agregat oleh limbah plastik. Untuk mengetahui kadar efektif plastik untuk bahan campuran beraspal, selanjutnya dilakukan percobaan pencampuran plastik. Penyerapan air oleh agregat dan ketahanan agregat terhadap gesekan (abrasi) merupakan sifat alami yang tidak dapat diperbaiki pada saat proses pemecahan di crussing plant. Agregat yang mempunyai penyerapan tinggi umumnya bersifat porous sehingga mempunyai ketahanan abrasi yang kurang baik. Selain itu, penggunaan agregat yang mempunyai penyerapan air tinggi sebagai bahan campuran beraspal, akan membutuhkan aspal yang banyak. Plastik yang dicampurkan ke agregat dalam kondisi panas akan memperbaiki kedua sifat tersebut. Untuk itu akan dilakukan pengujian pengaruh penambahan limbah plastik terhadap perubahan sifat penyerapan air dan ketahanan abrasi pada agregat kasar. Rentang kadar yang dipilih adalah $0 \%, 5 \%$, dan 10\%. Hasil uji adalah seperti pada Tabel 5.

Tabel 3. Hasil Pengujian Aspal Pen 60/70

\begin{tabular}{|c|c|c|c|}
\hline Jenis Uji & Hasil Uji & Spesifikasi & Satuan \\
\hline Penetrasi (dmm) & 63 & $60-70$ & $\mathrm{dmm}$ \\
\hline $\begin{array}{l}\text { Viskositas absolut } 60^{\circ} \mathrm{C} \\
(\mathrm{Pa} . \mathrm{S})\end{array}$ & 215,1 & $160-240$ & Pa. S \\
\hline Viskositas pada $135^{\circ} \mathrm{C}$ & 475 & $\geq 300$ & $\mathrm{cSt}$ \\
\hline Titik lembek & 50 & $\geq 48$ & ${ }^{\circ} \mathrm{C}$ \\
\hline Daktilitas & $>140$ & $\geq 100$ & $\mathrm{Cm}$ \\
\hline Titik Nyala & 319 & $\geq 232$ & ${ }^{\circ} \mathrm{C}$ \\
\hline $\begin{array}{l}\text { Kelarutan } \\
\mathrm{C}_{2} \mathrm{HCL}_{3}\end{array}$ & 99,91 & $\geq 99$ & $\%$ \\
\hline Berat Jenis & 1,039 & $\geq 1$ & - \\
\hline $\begin{array}{l}\text { Kehilangan } \\
\text { (TFOT) }\end{array}$ & 0,133 & $\leq 0,8$ & $\%$ \\
\hline $\begin{array}{l}\text { Viskositas } \\
\text { (TFOT) }\end{array}$ & 286 & $\leq 800$ & Pa. S \\
\hline
\end{tabular}

Tabel 4. Hasil Pengujian Plastik

\begin{tabular}{lcc}
\hline \multicolumn{1}{c}{ Jenis Uji } & Hasil Uji & Spesifikasi \\
\hline Kadar air & $4,5 \%$ & Maks. $5 \%$ \\
Ketebalan & $0,05 \mathrm{~mm}$ & Maks. $0,07 \mathrm{~mm}$ \\
\hline
\end{tabular}

Tabel 5. Perubahan sifat agregat dengan penambahan plastik

\begin{tabular}{lccc}
\hline \multirow{2}{*}{ Pengujian } & \multicolumn{3}{c}{ Kadar Plastik } \\
\cline { 2 - 4 } & $0 \%$ & $5 \%$ & $10 \%$ \\
\hline Abrasi (\%) & 20,4 & 17,2 & 16,5 \\
Penyerapan (\%) & 1,5 & 1,3 & 1,2 \\
\hline
\end{tabular}

Nilai persentase gesekan agregat yang rusak oleh alat uji abrasi pada agregat tanpa plastik adalah $20,4 \%$, terjadi peningkatan kekuatan agregat setelah ditambah plastik ke dalam agregat yang terbukti dengan turunnya nilai persentase kerusakan agregat yang turun menjadi $17,2 \%$ dan $16,5 \%$. Untuk uji penyerapan menunjukan bahwa penambahan plastik pada agregat menyebabkan nilai penyerapan menjadi kecil karena pori-pori agregat tertutup oleh limbah plastik. Ber- 
dasarkan hasil uji abrasi dan penyerapan, membuktikan bahwa penambahan plastik ke dalam agregat dapat meningkatkan kekuatan terhadap gesekan dan mengurangi penyerapan agregat.

Untuk mengetahui pengaruh penambahan dan kadar paling efektif limbah plastik terhadap karakteristik campuran dilakukan pengujian yang meliputi: pengujian karakteristik campuran menggunakan alat marshall, pengujian durabilitas campuran dengan alat indirect tensile strength rasio (ITSR), pengujian ketahanan campuran terhadap deformasi menggunakan alat wheel tacking machine (WTM), dan pengujian kekakuan campuran beraspal (modulus resilient)

Kadar plastik yang ditambahkan dalam campuran, ditentukan berdasarkan hasil uji abrasi dan penyerapan pada Tabel 4, dimana nilai hasil uji antara kadar plastik 5\% dan 10\% tidak jauh berbeda. Untuk itu kadar plastik dalam campuran diuji dalam lima variasi, yaitu $0 \%, 5 \%, 6 \%, 8 \%$ dan $9 \%$ terhadap berat aspal.

Hasil pengujian karakteristik campuran beraspal panas menggunakan alat marshall disajikan pada Tabel 6.

Berdasarkan uji marshall pada Tabel 6 yang paling signifikan adalah nilai stabilitas. Pada campuran tanpa limbah plastik nilai stabilitas adalah $1100 \mathrm{~kg}$, setelah ditambah plastik 5\%-9\% terdapat peningkatan mencapai $1424 \mathrm{~kg}$ sampai $1534 \mathrm{~kg}$. Peningkatan nilai stabilitas tersebut mencapai $>30 \%$. Hal ini berarti campuran beraspal dengan limbah plastik mempunyai kekuatan yang lebih tinggi untuk menahan beban dari pada campuran aspal tanpa limbah plastik.

Untuk mengetahui durabilitas campuran beraspal setelah ditambah limbah plastik, pada masing-masing kadar aspal optimum selanjutnya dilakukan pengujian stabilitas marshall sisa, pengujian indirect tensile strength ratio (ITSR) dan pengujiaan cantambroo. Hasil pengujian durabilitas adalah sesuai dengan Tabel 7.

Hasil uji durabilitas menunjukan bahwa stabilitas sisa dan kuat tarik campuran beraspal dengan limbah plastik mengalami peningkatan. Hal ini merupakan bukti bahwa campuran dengan limbah plastik lebih efektif dalam menahan beban kendaraan lalu lintas

Retak alur akibat beban lalu lintas dan tingginya temperatur merupakan salah satu perhatian utama untuk menilai kinerja perkerasan jalan. Untuk menyetahui ketahanan campuran beraspal dengan limbah plastik terhadap deformasi alur, maka dilakukan pengujian WTM. Pengujian deformasi terhadap pengaruh penambahan plastik dengan alat WTM dilakukan untuk mengetahui tiga parameter yaitu deformasi awal, stabilitas dinamis, dan kecepatan deformasi. Hasil pengujian dengan alat WTM adalah sesuai dengan Tabel 8.
Berdasarkan uji deformasi pada Tabel 7, terlihat bahwa dengan penambahan aspal palstik ke dalam campuran menyebabkan campuran aspal menjadi kaku karena pengaruh polimer dalam plastik. Hal ini terbukti dengan menurunnya nilai deformasi awal (Do) dan kecepatan deformasi. Menurunnya nilai Do dan kecepatan deformasi membuktikan bahwa campuran dengan limbah plastik lebih tahan terhadap beban roda kendaraan dibandingkan dengan campuran aspal tanpa limbah plastik. Selain itu penambahan limbah plastik dapat meningkatkan stabilitas dinamis sangat signifikan setelah ditambah plastik pada campuran aspal. Peningkatan nilai stabilitas dinamis ini terjadi karena meningkatnya daya lekat antara agregat dengan aspal yang disebabkan oleh proses pencampuran plastik dan agregat yang ditambah aspal dalam temperatur tinggi. Kontak antara aspal dan plastik pada kondisi tersebut, meningkatkan daya lekat sehingga berimbas pada peningkatan ketahanan deformasi campuran.

Untuk mengetahui pengaruh penambahan plastik terhadap tingkat sensitifitas campuran pada temperatur maka dilakukan pengujian modulus resilient pada temperatur $25^{\circ} \mathrm{C}$, $35^{\circ} \mathrm{C}$, dan $45^{\circ} \mathrm{C}$. Hasil pengujian disajikan dalam Tabel 9.

Tabel 6. Hasil Pengujian Campuran dengan Alat Marshall

\begin{tabular}{|c|c|c|c|c|c|}
\hline \multirow{2}{*}{ Kriteria Uji } & \multicolumn{5}{|c|}{ Campuran AC-WC dan \% Plastik } \\
\hline & $0 \%$ & $5 \%$ & $6 \%$ & $8 \%$ & $9 \%$ \\
\hline $\begin{array}{l}\text { Kadar Aspal } \\
\text { Optimum } \\
(\%)\end{array}$ & 5,8 & 5,8 & 5,8 & 5,8 & 5,8 \\
\hline $\begin{array}{l}\text { Kepadatan } \\
\left(\text { ton } / \mathrm{m}^{3}\right)\end{array}$ & 2,369 & 2,357 & 2,363 & 2,364 & 2,345 \\
\hline $\begin{array}{l}\text { Rongga } \\
\text { diantara } \\
\text { agregat }(\%)\end{array}$ & 15,82 & 15,89 & 15,74 & 15,68 & 16,34 \\
\hline $\begin{array}{l}\text { Rongga } \\
\text { terhadap } \\
\text { campuran } \\
(\%)\end{array}$ & 3,8 & 3,71 & 3,89 & 4,02 & 3,7 \\
\hline $\begin{array}{l}\text { Stabilitas } \\
(\mathrm{kg})\end{array}$ & 1100 & 1424 & 1486 & 1534 & 1528 \\
\hline $\begin{array}{l}\text { Kelelehan } \\
(\mathrm{mm})\end{array}$ & 4,11 & 3,59 & 4,1 & 4,2 & 4,14 \\
\hline $\begin{array}{l}\text { Marshal } \\
\text { Quitien } \\
(\mathrm{kg} / \mathrm{mm})\end{array}$ & 272,5 & 401,9 & 366,6 & 367,6 & 371,8 \\
\hline $\begin{array}{l}\text { Rasio abu } \\
\text { terhadap } \\
\text { aspal }\end{array}$ & 1,17 & 1,22 & 1,26 & 1,28 & 1,17 \\
\hline
\end{tabular}


Sesuai dengan Tabel 9, terlihat bahwa nilai modulus resilien akan turun dengan meningkatnya temperatur pengujian. Berdasarkan Tabel 5 dan Tabel 9, juga terlihat bahwa penambahan plastik mengakibatkan perubahan nilai modulus resilien pada campuran beraspal. Pada seluruh pengujian, nilai modulus resilent meningkat dengan peningkatan penambahan limbah plastik pada campuran beraspal. Hasil uji modulus resilien pada $6 \%$, $8 \%$, dan $9 \%$ diperoleh nilai yang tidak berbeda jauh. Ketiga nilai tersebut merupakan nilai yang paling efektif dalam campuran beraspal, namun harus disesuaikan dengan hasil uji lainnya.

Tabel 7. Durabilitas Campuran AC-WC yang Dipengaruhi Limbah Plastik

\begin{tabular}{|c|c|c|c|c|c|}
\hline \multirow{2}{*}{ Kriteria Uji } & \multicolumn{5}{|c|}{ Campuran AC-WC dan \% Plastik } \\
\hline & $0 \%$ & $5 \%$ & $6 \%$ & $8 \%$ & $9 \%$ \\
\hline $\begin{array}{l}\text { Stabilitas } \\
\text { marshall sisa } \\
(\%)\end{array}$ & 90,45 & 93,48 & 94,70 & 90,70 & 87,06 \\
\hline $\begin{array}{l}\text { Kuat Tarik tak } \\
\text { langsung (\%) }\end{array}$ & 76,7 & 84,8 & 83,7 & 80,2 & 79,1 \\
\hline Cantabro (\%) & 6,2 & 5,7 & 5,1 & 5,9 & 8,7 \\
\hline
\end{tabular}

Tabel 8. Hasil Uji Ketahanan Deformasi

\begin{tabular}{lccccc}
\hline \multirow{2}{*}{ Kriteria Uji } & \multicolumn{5}{c}{ Campuran AC-WC dan \% Plastik } \\
\cline { 2 - 6 } & $0 \%$ & $5 \%$ & $6 \%$ & $8 \%$ & $9 \%$ \\
\hline Do (mm) & 2,79 & 1,97 & 2,26 & 2,28 & 2,29 \\
Kecepatan & 0,08 & 0,023 & 0,023 & 0,021 & 0,001 \\
deformasi & & & & & \\
$(\mathrm{mm} /$ menit) & & & & & \\
$\begin{array}{l}\text { Stabilitas } \\
\text { Dinamis } \\
(\text { lintasan/mm) }\end{array}$ & 531 & 1828 & 1466 & 2333 & 4875 \\
\hline
\end{tabular}

Berdasarkan hasil empat pengujian tersebut dilakukan analisa untuk menentukan kadar efektif plastik dalam campuran. Hal uji marshall menunjukkan nilai stabilitas tertinggi ada pada plastik $8 \%$, namun pada kriteria uji yang lain nilai hasil uji antara kadar plastik $6 \%$ dan $8 \%$ tidak secara signifikan perbedaanya bahkan ada yang mengalami penurunan. Untuk hasil uji durabilitas campuran, nilai stabilitas sisa dan kuat tarik tak langsung tertinggi ada pada kadar plastik $6 \%$ setelah itu mengalami penurunan. Hal yang sama juga terjadi pada pengujian ketahanan deformasi dan modulus resilient, mayoritas menyalami penurunan setelah kadar plastik 6\%. Walaupun beberapa yang mengalami kenaikan setelah kadar plastik $6 \%$, namun nilai tersebut tidak terlalu signifikan perbedaanya. Berdasarkan empat hasil pengujian di atas, maka dapat ditentukan bahwa 6\% merupakan kadar yang paling efektif dari limbah plastik yang dicampurkan ke campuran AC-WC.

Tabel 9. Hasil Uji Modulus Resilient dengan Limbah Plastik

\begin{tabular}{cccccc}
\hline \multirow{2}{*}{ Temperatur } & \multicolumn{5}{c}{ Campuran AC-WC dan \% Plastik } \\
\cline { 2 - 6 } & $0 \%$ & $5 \%$ & $6 \%$ & $8 \%$ & $9 \%$ \\
\hline 25 & 2538 & 2789 & 3009 & 2880 & 3019 \\
35 & 620 & 750 & 812 & 941 & 889 \\
45 & 204 & 249 & 314 & 331 & 315 \\
\hline
\end{tabular}

Selain untuk menentukan kadar efektif plastik dalam campuran AC-WC, empat pengujian di atas juga dapat membuktikan bahwa dengan penambahan limbah plastik cacah ke dalam campuran dapat meningkatkan mutu campuran. Hal tersebut terlihat dari meningkatkan nilai stabilitas dan nilai lainnya dalam campuran AC-WC setelah ada penambahan limbah plastik.

\section{Pengujian Campuran AC-WC}

Berdasarkan hasil uji kadar paling efektif plastik dalam campuran beraspal di atas, maka penerapan lapangan campuran AC-WC dengan limbah plastik dilaksanakan dengan menambahkan kadar plastik yang paling efektif yaitu $6 \%$ dari berat aspal. Perencanaan rancangan campuran diawali dengan perencanaan gradasi agregat untuk campuran ACWC. Gradasi campuran agregat adalah sesuai dengan

\section{Gambar 1.}

Berdasarkan gradasi campuran agregat dari hotbin tersebut selanjutnya dilakukan percobaan marshall untuk menentukan karakteristik campuran beraspal dan kadar aspal optimum. Adapun resume dari percobaan marshall campuran beraspal Pen 60/70 dengan limbah plastik disajikan pada Tabel 10.

Data perencanaan tersebut merupakan JMF dan digunakan sebagai dasar pelaksanaan penerapan campuran AC-WC dengan limbah plastik di lapangan.

\section{Pengujian Kepadatan}

Data kepadatan lapangan diperoleh dari pengambilan sampel core drill. Pada penelitian ini, pengambilan sampel dilakukan di 5 titik per 50m. Nilai kepadatan lapangan kemudian dibandingkan terhadap kepadatan rencana di laboratorium. Hasil pengujian kepadatan lapangan dan nilai JSD sesuai dengan Tabel 11.

Berdasarkan hasil perhitungan nilai JSD, diperoleh nilai JSD yang lebih kecil dari 98\%, sesuai Spesifikasi Umum Bina Marga 2018. Faktor jumlah lintasan pemadatan diduga merupakan hal yang mempengaruhi nilai kepadatan pada penerapan penelitian ini. Panjang lokasi penerapan yang hanya 300m, menyebabkan tidak mungkin dilakukan trial 
compaction. Jumlah lintasan pada penelitian ini adalah 20 lintasan.

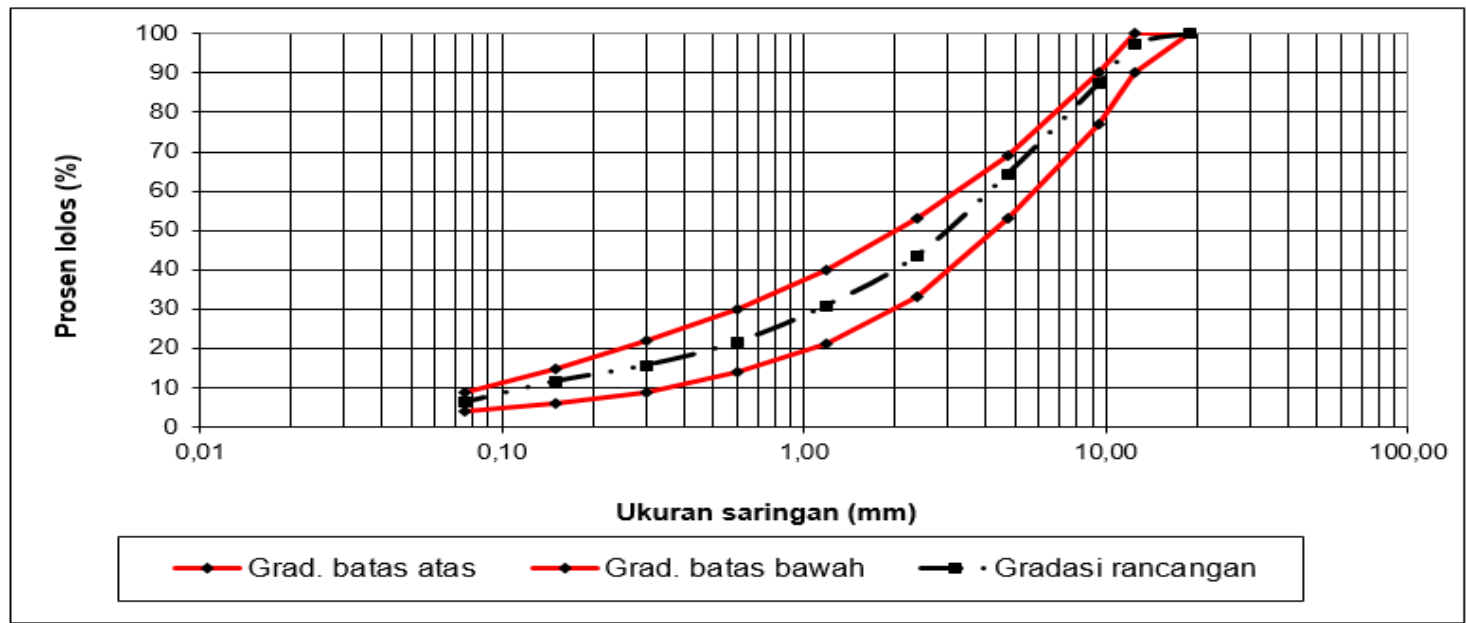

Gambar 1. Gradasi Agregat Campuran Hotbin

Tabel 10. Hasil Uji Marshal untuk Campuran AC-WC

\begin{tabular}{|c|c|c|c|}
\hline Kriteria Uji & Hasil Uji & Spesifikasi & Satuan \\
\hline $\begin{array}{l}\text { Kadar aspal } \\
\text { efektif }\end{array}$ & 6,0 & & $\%$ \\
\hline Kepadatan & 2,252 & & $\mathrm{t} / \mathrm{m}^{3}$ \\
\hline VMA & 16,3 & Min. 15 & $\%$ \\
\hline VIM Marshall & 3,8 & $3-5$ & $\%$ \\
\hline VFB & 76,4 & Min. 65 & $\%$ \\
\hline Stabilitas & 1604,5 & Min. 900 & $\mathrm{~kg}$ \\
\hline $\begin{array}{l}\text { Kelelehan aspal } \\
\text { karet }\end{array}$ & - & $2-5$ & $\mathrm{~mm}$ \\
\hline $\begin{array}{l}\text { Kelelehan aspal } \\
\text { plastik }\end{array}$ & 3,39 & $2-4$ & $\mathrm{~mm}$ \\
\hline Rasio filler & 1,1 & $1-1,4$ & $\%$ \\
\hline
\end{tabular}

Tabel 11. Hasil Uji Kepadatan Lapangan dan Nilai JSD

\begin{tabular}{|c|c|c|c|c|}
\hline \multirow{2}{*}{ STA } & \multirow{2}{*}{$\begin{array}{l}\text { Tebal } \\
(\mathrm{cm})\end{array}$} & \multicolumn{2}{|c|}{ Kepadatan (gr/cc) } & \multirow{2}{*}{$\begin{array}{l}\text { JSD } \\
(\%)\end{array}$} \\
\hline & & Laboratorium & Lapangan & \\
\hline $0+150 \mathrm{R}$ & 6,52 & & 2,169 & 96,33 \\
\hline $0+200 \mathrm{C}$ & 5,89 & & 2,173 & 96.50 \\
\hline $0+250 \mathrm{~L}$ & 4,42 & 2,252 & 2,173 & 96.50 \\
\hline $0+300 \mathrm{R}$ & 6,35 & & 2,170 & 96,35 \\
\hline $0+350 \mathrm{C}$ & 5,91 & & 2,191 & 97,31 \\
\hline
\end{tabular}

\section{Pengujian Ekstraksi}

Analisis terhadap hasil uji ekstrakasi dilakukan dengan cara membandingkan hasil uji dengan perencanaan di JMF. Perbandingan dilakukan terhadap kadar aspal dan gradasi rencana terhadap hasil uji ekstraksi. Untuk kadar aspal syarat spesifikasi adalah +/-0,3 terhadap kadar aspal rencana.
Sementara untuk gradasi persyaratan spesifikasi adalah $+/-5$ untuk saringan nomor 1/2", 3/8", 4, dan +/-3 untuk saringan nomor $8,16,30$, serta $+/-2$ untuk saringan nomor 100 dan 200. Hasil ektraksi campuran AC-WC dengan limbah plastik adalah sesuai dengan Tabel 12.

Tabel 12. Hasil Uji Ekstraksi Campuran AC-WC dengan Limbah Plastik

\begin{tabular}{lrcc}
\hline \multicolumn{1}{c}{ Pengujian } & JMF & Hasil Ekstraksi & Speksifikasi \\
\hline $\begin{array}{l}\text { Kadar Aspal } \\
\text { Gradasi }\end{array}$ & $6 \%$ & $5,79 \%$ & $+/-0,3$ \\
\#3/4" & 100,0 & 100 & \\
\#1/2" & 97,2 & 96,96 & $+/-5$ \\
\#3/8" & 87,4 & 85,86 & $+/-5$ \\
\# No. 4 & 64,4 & 65,56 & $+/-5$ \\
\# No. 8 & 43,5 & 43,85 & $+/-5$ \\
\# No. 16 & 30,8 & 30,14 & $+/-3$ \\
\# No. 30 & 21,6 & 22,07 & $+/-3$ \\
\# No. 50 & 15,6 & 16,26 & $+/-3$ \\
\# No. 100 & 11,6 & 11,91 & $+/-2$ \\
\# No. 200 & 6,3 & 7,54 & $+/-2$ \\
\hline
\end{tabular}

Berdasarkan pengujian ektraksi, nilai hasil pengujian menunjukan bahwa antara JMF dan campuran AC-WC di lapangan tidak terdapat perbedaan yang signifikan. Perbedaan nilai JMF dan hasil lapangan masih berada dalam range yang dipersyaratkan oleh spesifikasi. Hal ini berarti bahwa perencanaan dan penambahan limbah plastik kresek dapat diterapkan dengan baik di lapangan.

\section{Pengujian Ketidakrataan}


Pada penelitian ini untuk mengetahui ketidakrataan permukaan perkerasan campuran aspal dengan limbah plastik dilakukan dengan alat walking profimeter.

Pengujian dilakukan pada bulan keenam setelah penghamparan campuran AC-WC dengan limbah plastik.

Berdasarkan hasil pengujian, nilai IRI terendah yaitu 3,63 pada STA $0+110$, dan nilai IRI tertinggi yaitu 7,56 diperoleh pada STA $0+220$. Nilai rata-rata IRI pada lokasi penerapan ini adalah 4,75. Hasil uji ketidakrataan adalah sesuai dengan

\section{Gambar 2.}

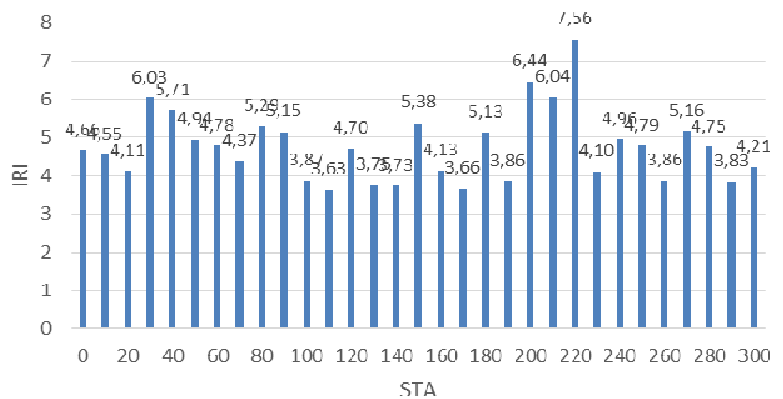

Gambar 2. Hasil Uji Ketidakrataan

Hasil uji ketidakrataan, menunjukan bahwa campuran AC-WC yang ditambahkan limbah plastik kresek mempunyai nilai antara baik $(<4)$ dan sedang (4-8). Prosentase nilai kondisi perkerasan berdasarkan IRI adalah sesuai dengan Tabel 13.

Tabel 13. Prosentase nilai perkerasan berdasarkan IRI

\begin{tabular}{ccl}
\hline Nilai IRI & Prosentase & \multicolumn{1}{c}{ Kondisi } \\
\hline$<4$ & $25,81 \%$ & Baik \\
$4-8$ & $74,19 \%$ & Sedang \\
$8-12$ & - & Rusak Ringan \\
$>12$ & - & Rusak Berat \\
\hline
\end{tabular}

Berdasarkan prosentase nilai IRI tersebut, membuktikan bahwa perkerasan dengan campuran AC-WC yang ditambah limbah plastik mempunyai kinerja yang baik sampai sedang. Terbukti setelah 6 bulan kinerja perkerasan tidak ada yang mengalami kerusakan ringan maupun berat. Mayoritas nilai IRI yang dalam kondisi sedang disebabkan oleh kondisi perkerasan eksisting yang sebelumnya berupa lapis penetrasi yang bergelombang.

\section{Simpulan}

Berdasarkan hasil analisis, penambahan limbah plastik kresek pada campuran beraspal AC-WC dapat meningkatkan mutu campuran. Penambahan plastik ke agregat dapat meningkatkan kekuatan agregat terhadap abrasi dan mengurangi penyerapan.

Hasil uji marshall, menunjukan bahwa campuran beraspal dengan limbah plastik mempunyai kekuatan yang lebih tinggi untuk menahan beban dari pada campuran aspal tanpa limbah plastik. Hal ini terbukti dengan meningkatkanya nilai stabilitas yang meningkat $>30 \%$ setelah ditambah plastik.

Hasil uji durabilitas campuran AC-WC dengan limbah plastik menunjukan meningkatan nilai stabilitas sisa. Hasil uji terhadap ketahanan deformasi menunjukkan campuran beraspal dengan ditambahkan limbah plastik kresek lebih tahan terhadap deformasi yang ditunjukan dengan nilai stabilitas dinamis yang meningkat. Selain itu, penambahan plastik pada campuran dapat meningkatkan nilai modulus resilien pada campuran beraspal.

Berdasarkan hasil pengujian marshall, durabilitas, ketahanan deformasi, dan modulus resilien, nilai kadar limbah plastik yang paling efektif dalam campuran beraspal AC-WC adalah $6 \%$ terhadap berat aspal yang digunakan.

Hasil uji ektraksi, menunjukan kadar aspal dan gradasi agregat tidak berbeda jauh dari perencanaan desain campuran. Hal ini berarti campuran beraspal AC-WC dengan ditambahkan limbah plastik kresek dapat diterapkan dengan baik di lapangan.

Untuk pengujian ketidakrataan diperoleh nilai IRI yaitu $<4$ sebesar $25,81 \%$ dan nilai $4-8$ sebesar $74,19 \%$. Berdasarkan hasil nilai IRI maka dapat disimpulkan bahwa campuran tersebut mampu memberikan kinerja yang baik dalam menahan beban lalu lintas, terbukti selama enam bulan belum terdapat nilai kondiri rusak ringan atau berat.

\section{Daftar Pustaka}

[1] I. Susanto dan Nono, "Pengujian Material Lokal sebagai Bahan Perkerasan Jalan di Pulau Terpencil dan Terluar" Widyariset, vol. 4, no. 1, pp. 61-74, 2018.

[2] Direktorat Jenderal Bina Marga, "Spesifikasi umum 2018" Bina Marga, Kementerian Pekerjaan Umum dan Perumahan Rakyat, Jakarta, 2018.

[3] I. Susanto, Penerapan Terbatas Aspal Plastik dan Aspal Karet di Jalan Lingkungan Pusjatan, Pertama. Bandung: Puslitang Jalan dan Jembatan, Balitbang, Kementerian Pekerjaan Umum dan Perumahan Rakyat, 2018.

[4] E. Kurniawan and I. Sari, "Pengolahan Limbah Kantong Plastik Jenis Kresek menjadi Bahan Bakar Menggunakan Proses Pirolisis” J. Energi Elektr., vol. IV, no. 1, pp. 1-5, 2015.

[5] M. Z. Arifin, "Dampak Sampah Plastik Bagi Ekosistem Laut" Bul. Matric, vol. 14, no. 1, pp. 44 48, 2017.

[6] U. B. Surono, "Berbagai Metode Konversi Sampah Plastik" J. Tek., vol. 3, no. 1, pp. 32-40, 2013.

[7] B. Sengoz and G. Isikyakar, "Analysis Of StyreneButadiene-Styrene Polymer Modified Bitumen Using Fluorescent Microscopy and Conventional Test 
Methods," J. Hazard. Mater, vol. 150, no. 2, pp. 424432, 2008.

[8] Y. Yetkin, "Polymer Modified Asphalt Binders" Constr. Build. Mater., vol. 21, no. 1, pp. 66-72, 2007.

[9] I. R. Congress, Guidelines for the use of Waste Plastic in Hot Bituminous Mixes (Dry Process) In Wearing Courses. 2013.

[10] N. Suaryana, E. Nirwan, and Y. Ronny, "Plastic Bag Waste on Hotmixture Asphalt as Modifier Plastic Bag Waste on Hotmixture Asphalt as Modifier" Key Eng. Mater., vol. 789, pp. 20-25, 2018.

[11] Pusjatan, "Teknologi Perkerasan Lentur dengan Aspal Karet Masterbatch" 2017.

[12] V. C. Pangemanan, O. H. Kaseke, and M. R. E. Manoppo, "Pengaruh Suhu dan Durasi Terendamnya Perkerasan Beraspal Panas Terhadap Stabilitas dan Kelelehan (Fow)" J. Sipil Statik, vol. 3, no. 2, pp. 8590, 2015.

[13] Y. Huang, "Pavement Analysis and Design, New Jersey," Second Edi., USA: Prentice Hall, 2004.

[14] N. Suaryana et al., "Evaluasi Kinerja Campuran Beraspal dengan Bitumen Hasil Ekstraksi Penuh dari Asbuton" Media Komunikasi Tek. Sipil, vol. 24, no. 1, pp. 62-70, 2018.

[15] NCHRP, "Guide for Mechanistic-Empirical Design, Part 3 Chapter 3 Flexibe Design" National Research Council, Washington, D.C, 2004.

[16] V. Dubois, C. D. La Roche, and O. Burban, "Influence Of The Compaction Process On The Air Void Homogeneity Of Asphalt Mixtures Samples" Constr. Build. Mater, vol. 24, no. 6, pp. 885-897, 2010.

[17] C. Oglesby and R. Hicks, Teknik Jalan Raya. Jakarta: Erlangga, 1997.

[18] Masykur, "Analisis Pengujian Gradasi Ekstraksi Campuran AC-BC" Tapak, vol. 6, no. 1, pp. 30-43, 2016.

[19] Suherman, "Studi Persamaan Korelasi antara Ketidakrataan Permukaan Jalan dengan Indeks Kondisi Jalan Studi Kasus Ruas Jalan LabuanCibaliung," J. Tek. Sipil, vol. 8, no. 3, pp. 206-214, 2008.

[20] M. Y. M. Putra, B. Sugeng Subagio, E. S. Hariadi, and S. Hendarto, "Evaluasi Kondisi Fungsional dan Struktural Menggunakan Metode Bina Marga dan AASHTO 1993 Sebagai Dasar dalam Penanganan Perkerasan Lentur Studi Kasus : Ruas Medan - Lubuk Pakam," J. Tek. Pomits, vol. 20, no. 3, pp. 245-254, 2013.

[21] D. B. Program, Manual Survei Kondisi Jalan. Jakarta: Kementerian Pekerjaan Umum dan Perumahan Rakyat, 2011. 